GLOBAL JOURNAL OF AGRICULTURAL SCIENCES VOL. 17, 2018: 55-64

COPYRIGHT@ BACHUDO SCIENCE CO. LTD PRINTED IN NIGERIA ISSN 1596-2903

\title{
GENOTYPE X ENVIRONMENT INTERACTION FOR FRUIT YIELD OF SOME CUCUMBER (Cucumissativus) GENOTYPES
}

\author{
A.G. IWO AND O.E. ODOR \\ (Received 30 ${ }^{\text {th }}$ March 2017; Revision Accepted 16 October 2017)
}

\begin{abstract}
The present study was performed to analyze the genotype $x$ environment ( $\mathrm{G} \times \mathrm{E}$ ) interaction for fruit yield of 5 genotypes in four environments; Ikom, Calabar, Obubra and Obudu located at different agro-ecological zones of Cross River State. The cucumber genotypes were grown in randomized complete block design in three replicates in 2015 cropping season. The yield data was analyzed using additive main effect and multiplicative interaction (AMMI) and genotype plus genotype by environment (GGE). Additive main effect and multiplicative interaction (AMMI) analysis of variance showed statistically significant effect of genotypes, environments and the genotype $x$ environment interaction $(P<0.01 \%)$. The environment explained $59.59 \%$ which showed high differences in variety response to different locations tested. Genotype $(G)$ and genotype $x$ environment interaction ( $G \times E$ ) accounted $15.83 \%$ and $11.89 \%$ respectively. The first interaction principal component axis (IPCA1) was significant $(P<0.01)$ except the (IPCA 2) and explained $11.50 \%$ and $0.36 \%$ of the GX E sum of squares respectively. The Additive main effect and multiplicative interaction stability value (ASV) showed that significant difference existed in the $G \times E$ component. Based on the stability parameters, it revealed that none of the genotypes were stable for fruit yield, however according to ASV, and GGE Bi-plot graphical representation, Ashley genotype in relative terms was stable. The genotypes Poinsett $\left(48.43 \mathrm{t} \mathrm{ha}^{-1}\right)$,Ashley $\left(47.49 \mathrm{t} \mathrm{ha}^{-1}\right)$ and Marketer $\left(41.66 \mathrm{t} \mathrm{ha}^{-1}\right)$ were considered to have adaptability to favorable environments, while Market More (MM 13.97t ha-1) and Super Marketer (SM $16.66 \mathrm{t} \mathrm{ha}^{-1}$ ) adapted to unfavorable conditions for fruit yield. Based on AMMI and GGE bi-plot, ASL had the widest adaptation and was considered as the ideal genotype, whereas P.ST showed specific adaptation. The ideal environments were IKOM $\left(66.85 \mathrm{t} \mathrm{ha}^{-1}\right)$ and OBURA $\left(56.93 \mathrm{t} \mathrm{ha}^{-1}\right)$. Through the GGE bi-plot and AMMI analysis, the superior genotypes identified could serve as references for genotype evaluation and inclusion in further testing in other seasons and environments.
\end{abstract}

KEYWORD: Environment, Genotype, Interaction, Stability and Yield

\section{INTRODUCTION}

Cucumber (CucumissativusL) is an economically important crop in the family,Cucurbitaceae. There are seventy genera and seven hundred and fifty species of cucumberswithin the family (Thoa, 1998 and Best, 2000). Cucumber origin is traced to Asia and Africa where it has been utilized for over 3,300 years, however great number of cultivars have emerged and are widely grown and are consumed globally (Hector et al., 1989). There are three main types of cucumber which include; slicing, pickling and burp types within which several cultivars have been developed.Cucumber is the second largest of all cucurbits and the fourth most cultivated vegetable globally (Jack et al., 2008). Agricultural land under cucumber production worldwide is nine million hectares with yields of 184 million tons. China is the highest producer of cucumber with global output of $76 \%$, followed by Turkey, Iran, Russia and Ukraine (FAO,
2015).

The nutritional profile of cucumber has revealed that cucumber provides phytonutrients which are beneficiary to health. These include flavonoids (such as apigenin, luteolin, quercetin and kaempferol), lignans (such as pinoresinol, lariciresinol and seciosolariciresinol) and triterpenes (cucurbitacines $\mathrm{A}, \mathrm{B}$ and $\mathrm{C}$ ). Lee et al.,(2010), and Thoennissen et al., (2009) maintained that the plant phytonutrients especially the lignans are potent in reducing cardiovascular diseases and also various cancer types. The nutritional composition of cucumber shows that a fruit of cucumber per $100 \%$ edible portion contains $3 \%$ carbohydrate, $1 \%$ protein, $0.5 \%$ fat and $1 \%$ fibre, cucumbers are also excellent sources of vitamins $\mathrm{K}, \mathrm{C}$ and $\mathrm{B}_{1}$, and minerals like Molybdenum, Potassium, Manganese, Phosphorous, Magnesium, Copper. Cucumber is a very rich source of hair and nails promoting, silica. Other nutrients include pantothenic acid and biotin (USDA, 2014).

ODOR, E.O: Department of Crop Science, University of Calabar, Calabar. PMB 1115, Calabar, Cross River State Nigeria. IWO, G.A: Department of Crop Science, University of Calabar, Calabar. PMB 1115, Calabar, Cross River State Nigeria. 
Multi-environment trials (MET) are conducted to evaluate yield stability performance of genetic materials under varying environmental conditions (Delacy et al., 1996; Yan et al., 2000; Yan and Rajcan, 2002). A genotype grown in different environments will frequently show significant fluctuations in yield performance. These changes are influenced by the different environmental conditions and are referred to as genotype-byenvironment (GE) interaction (Allard and Bradshow, 1964). However, GE interaction reduces the genetic progress in plant breeding programs through minimizing the association between phenotypic and genotypic values (Comstock and Moll, 1963). Hence, GE interaction must be either exploited by selecting superior genotype for each specific target environment or avoided by selecting widely adapted and stable genotype across wide range of environments (Ceccarelli, 1989).

In Nigeria, cucumber production is commonly carried out in the middle belt agro-ecological zone where it is believed to be well adapted; although few places in the southern part of the countrygrow it. Multi-location trial provides sufficient method of assessing varietal adaptation, yield and its stability.With the rising knowledge of the health benefits of cucumber and the agribusiness opportunity that lies in its production, due to the agrarian nature of the state and in the humid tropics with bimodal weather condition holds great potentials for cucumber production. Notwithstanding, little or no details on cucumber response to different environments and yield stability in Cross River States is known. Therefore, to investigate genotype $x$ environment interaction on yield and yield stability in Cross River State to reduce the genotype and environment selection complications necessitated this research in four locations namely, Calabar, Ikom, Obudu and Obubra across the state.

Therefore, the purpose of the study was to investigate the interaction between cucumber genotypes and environments in four locations in Cross River State; to determine the yield stability of cucumber genotypes across the different locations and to identify specific genotypes and their ideal environments.

\section{MATERIALS AND METHODS}

i. $\quad$ GGE Model: $Y_{i j}-u-\beta_{j}=\alpha_{i}+j_{i j \ldots}$

ii. $\quad$ AMMI Model: $Y_{i j}-u-\beta_{j}-\alpha_{i}=j_{i j}$

Where $Y_{i j}$ is the measure mean of the ith genotype in jth environment, $\mu$ is the grand mean, $a_{i}$ is the main effect of ith genotype, $\beta_{j}$ is the main effect of the $j$ th environment, $\mathrm{j}_{j j}$ is the interaction betweenith genotype and $j$ th environment.

\section{Additive Main Effect and Multiplicative Interaction (AMMI) Stability analysis value}

The AMMI and the GGE bi-plot were computed with the use of Plant Breeding Tool and R-Package software (IRRI 2007) and GGE bi-plot software version 4 (Yan 2000) model. The nature of genotype $x$ environment interaction was investigated with the use of AMMI model which combines the standard analysis of variance with principal component analysis (Zobelet al., 1988). Genotype stability ranking in these studies was calculated using the formulaby Purchase (1997) as follows

$\mathrm{ASV}=\sqrt{\left[\frac{\text { SSIPCA1 }}{\text { SSIPCA2 }}(\text { IPCA1Score })\right]^{2}+[\text { IPCA2Score }]^{2}}$

ASV = AMMI Stability Value

SSIPCA=Interactive Principal Component Analysis Sum of squares 1 and 2.

IPCA1Score $=$ Interactive Principal Component Analysis 1and 2 Scores.

The GGE bi-plot methodology (Yan et al., 2000) was used to graphically analyze the genotype x environment interaction data.
The study was carried out during the early cropping (n) four locations in 2015: Obudu $\left(6^{0} .40 \mathrm{~N}, 9^{0} .10\right.$ $2000 \mathrm{~mm}$ to $3000 \mathrm{~mm}$ it has temperature range of between $18^{\circ} \mathrm{C}$ to $40^{\circ} \mathrm{C}$ with optimum temperature of $\left.29^{0} \mathrm{C}\right)$ lkom $\left(5^{0} .57 .40 \mathrm{~N}, 8^{0} 42.39 \mathrm{E}\right.$ average rainfall $2332 \mathrm{~mm}$ and temperature of $\left.26^{\circ} \mathrm{C}\right)$ Obubra $\left(6^{\circ} .05 .0 \mathrm{~N}\right.$, $20 \mathrm{E}$, average annual rainfall of $2250-2500 \mathrm{~mm}$ and $8^{0} 21^{\prime \prime} \mathrm{E}$ average annual rainfall of $2915-3500 \mathrm{~mm}$ with optimum temperature of between $24-26^{\circ} \mathrm{C}$ ). These ocations represent the different agro-ecological zones in commercial cucumber genotypes: Ashley (ASL), Market more (MM), Marketer (MK), Poinsett (P.ST) and Supper (SM) were obtained from the National Institute Nigeria.

The experimental sites were cleared and plots of $5 \mathrm{~m}$ by dimension were made manually. The experiment three replications. The entire plot size measured $17 \mathrm{~m} \mathrm{x}$ $15 \mathrm{~m}\left(255 \mathrm{~m}^{2}\right)$ and was separated by $1 \mathrm{~m}$ alley way. Each was made up of three (3) rows of $5 \mathrm{~m}$ in length. Two $2 \mathrm{~cm}$ and a spacing of $1 \mathrm{~m} \times 0.5$. This was later thinned to one plant per stand after emergence. Data were reduce border effect for the following attributes: vine length at 3, 5 and 8 weeks after planting, number of primary lateral vines at 5 and 8 weeks after planting. of fruits per net plot, fruit weight and total fruit yield) were determined at harvest. The total yield was apolated to tonnes per hectare. Management staking were carried out in the four locations.

A combined analysis of variance (ANOVA) was carried the significant genotype by interaction was analytical tools. The means of all parameters were recorded. The Duncan Multiple Range Test (DMRT) probability level. AMMI and GGE bi-plot models wereused to analysedgenotype by environment interaction. 


\section{RESULTS AND DISCUSSION}

The results of the combined analysis of variance (ANOVA) for both growth and yield parameters of the five genotypes over four environments revealed differences in sources of variations of which environment $(E)$ and genotype $(G)$ for all the characters measured were highly significant at $P<0.01$ except for genotype fruit diameter(Table 1). The $G \times E$ was not significant at both $(P<0.01$ and $P<0.05)$ for all growth characteristics examined except for lateral vine at eight (8) weeks after sowing $(P<0.05)$. Among all the yield characters studied, genotype $(G)$ and interaction $(G \times E)$ were not significant in fruit diameter (FD). However, they were significant in numbers of fruits per plot (NFP), fruit length (FL) fruit weight (FW) and total fruit yield (TFY) in tonnes per hectare (Table 1). The implication is that there is genotype discrimination among the locations, (agro ecological zones), (Nzuveet al., 2013). Similar significant $G \times E$ results was reported by Thankiet al.,(2010), Dereraet al. (2008), Makumbi, (2005); on durum wheat. The relative sizes of the sources of variability differed as revealed by their variance components in(Table 1). The environment sum of squares revealed that the locations selected differ significantly causing the variations observed in the fruit yield.

Themeans yield and growth parameters for cucumber genotypes under combined analysis are shown in Table 2 . The result showed significant differences $(P<0.01)$ in the mean yield of genotypes revealing variability in the genetic constitution of the genotypes; conferring the possibility of these genotypes as source of breeding materials to create new varieties with better performance than the parent lines. The mean yield ranged between $48.43 \mathrm{tha}^{-1}$ for Poinsett, and $13.96 \mathrm{tha}^{-}$ ${ }^{1}$ for Market More. The genotypes Poinsett (P.ST), Ashley (ASL) and Marketer (MK), were consistently high yielders across the environment with mean fruit yields of $48.43,47.49$ and $41.66 \mathrm{t} \mathrm{ha}^{-1}$ respectively that exceeded the grand mean $\left(33.46 \mathrm{t} \mathrm{ha}^{-1}\right)$. The genotypes Market More and Super market (13.97 and 16.66 tha $^{-1}$ ) had the lowest mean yields. There were differences in genotype response to different environments for fruit and other yield parameters.

The mean yield results for four environments used for genotype $x$ environment findings, is presented are presented in (Table 3).

Concerning yield across environments, the highest mean fruit yield $\left(\right.$ tha $^{-1}$ ) were recorded at $\mathrm{lkom}$ and Obudu with overall mean fruit yields (66.85 and 56.93 tha $^{-1}$ ) respectively. This indicated that the two environments are favourable or suitable for cucumber production. All the genotypes performed well and gave mean fruit yields higher than the grand mean. Ikom (IK) recorded $\left(66.8 \mathrm{tha}^{-1}\right)$ as the highest mean fruit yield and Calabar (CAL) recorded $\left(0.53\right.$ tha $\left.^{-1}\right)$ as the lowest mean fruit yield. There was significant difference in location at $(P<0.05 \%)$ for vine length, lateral vine (growth attributes) and number of fruits per net plot across the time intervals of measurement but was not significantly different from Obudu in yield and yield components like fruit length fruit diameter and fruit weight. Ikom was significantly different from other locations. Obudu andObubra showed no location difference but were different from CAL in all the attributes evaluated.

Table 1: Mean squares from combined ANOVA for yield and growth parameters of five cucumber genotypes over four environments

\begin{tabular}{|c|c|c|c|c|c|c|c|c|c|c|c|}
\hline sov & Df & $\begin{array}{l}\text { VL21DA } \\
P(\mathrm{~cm})\end{array}$ & $\begin{array}{l}\text { VL5WA } \\
\mathrm{P}(\mathrm{cm})\end{array}$ & $\begin{array}{l}\text { VL8WA } \\
\mathrm{P}(\mathrm{cm})\end{array}$ & $\begin{array}{l}\text { LV5WA } \\
\mathrm{P}\end{array}$ & $\begin{array}{l}\text { LV8WA } \\
\mathrm{P}\end{array}$ & NFP & $\begin{array}{l}\mathrm{FL} \\
\mathrm{cm})\end{array}$ & $\begin{array}{l}\text { FD } \\
(\mathrm{cm})\end{array}$ & $\begin{array}{l}\mathrm{FW} \\
(\mathrm{kg})\end{array}$ & $\begin{array}{l}\text { TFY } \\
\text { t/ha }\end{array}$ \\
\hline Rep & 2 & 4.730 & 0.9644 & 1745.8 & 0.9644 & 6.448 & 462.5 & 13.043 & 56.17 & 37.20 & 57.21 \\
\hline$E$ & 3 & $\underset{* *}{132.779}$ & $\begin{array}{l}33.1696 \\
* *\end{array}$ & ${ }_{* *}^{71671.2}$ & $\underset{* *}{33.1696}$ & ${ }_{* *}^{153.152}$ & $\begin{array}{l}14127.2 \\
* *\end{array}$ & $\underset{* *}{748.930}$ & $\begin{array}{l}117.5 \\
5^{\star}\end{array}$ & $\begin{array}{l}1145.6 \\
2^{*}\end{array}$ & $17.62^{*}$ \\
\hline G & 4 & $36.185^{\star *}$ & $5.3495^{\star *}$ & $5732.6^{* *}$ & $5.3495^{\star *}$ & $12.610^{\star *}$ & $3418.8^{* *}$ & $66.385^{\star *}$ & $\begin{array}{l}23.26 \\
\text { ns }\end{array}$ & ${ }_{*}^{228.33^{*}}$ & ${ }_{*}^{35.11^{*}}$ \\
\hline $\begin{array}{l}\mathbf{G} \\
\mathrm{E}\end{array}$ & $\begin{array}{l}1 \\
2\end{array}$ & $1.515 \mathrm{~ns}$ & $\begin{array}{l}0.4211 \\
\text { ns }\end{array}$ & $\begin{array}{l}1269.9 \\
\text { ns }\end{array}$ & $\begin{array}{l}0.4211 \\
\mathrm{~ns}\end{array}$ & $6.205^{\star}$ & $764.1^{*}$ & $33.128^{* *}$ & $\begin{array}{l}47.08 \\
\text { ns }\end{array}$ & $57.15^{\star}$ & $87.88^{*}$ \\
\hline $\begin{array}{l}\text { Erro } \\
\mathbf{r}\end{array}$ & $\begin{array}{l}3 \\
8 \\
\end{array}$ & 3.343 & 0.8922 & 978.6 & 0.8922 & 1.893 & 227.9 & 5.393 & 36.56 & 17.28 & 26571 \\
\hline
\end{tabular}

${ }^{*}$ And * = significant level at $\mathrm{P}<0.01$ and $\mathrm{P}<0.05$ respectively; ns=not significant; and $\mathrm{df}=$ degree of Freedom, $\mathrm{E}=$ environment; $\mathrm{G}=$ genotype; $\mathrm{GEI}$ = genotype environment interaction

Parameters:VL21DAP = Vine length at 21 days after planting, VL5WAP = Vine length at 5 weeks after planting,VL8WAP $=$ Vine length at 8 weeks after planting, LV5WAP= Lateral vines at 5 weeks after planting,LV8WAP= Lateral vines at 8 weeks after planting, $\mathrm{FL}=$ Length of fruit, $\mathrm{FD}=$ Diameter of fruit,

$\mathrm{FW}=$ Weight of fruit, NFP $=$ Fruit number per plot, TFY $=$ Fruit yield total

Table2: Means for yield and growth parameters in cucumber genotypes under combined Analyses 


\begin{tabular}{|c|c|c|c|c|c|c|c|c|c|c|}
\hline $\begin{array}{l}\text { Envir } \\
\text { onme } \\
\text { nt }\end{array}$ & $\begin{array}{l}\text { VL21D } \\
\text { AP } \\
(\mathrm{cm})\end{array}$ & $\begin{array}{l}\text { VL5WAP( } \\
\mathrm{cm})\end{array}$ & $\begin{array}{l}\text { VL8W } \\
\text { AP } \\
(\mathrm{cm})\end{array}$ & $\begin{array}{l}\text { LV5W } \\
\text { AP } \\
(\mathrm{cm})\end{array}$ & $\begin{array}{l}\text { LV8 } \\
\text { WAP } \\
(\mathrm{cm})\end{array}$ & NFP & $\begin{array}{l}\text { FL } \\
(\mathrm{cm})\end{array}$ & $\begin{array}{l}\text { FD } \\
(\mathrm{cm})\end{array}$ & $\begin{array}{l}\text { FW } \\
(\mathrm{kg}\end{array}$ & TFY $\mathrm{t} \mathrm{ha}^{-1}$ \\
\hline CAL & $2.54_{c}$ & $17.92^{\mathrm{c}}$ & $34.37^{\mathrm{c}}$ & $0.37^{c}$ & $0.90^{\mathrm{d}}$ & $0.33^{d}$ & $4.13^{c}$ & $1.39^{b}$ & $0.04^{b}$ & $0.53^{b}$ \\
\hline IK & $9.61^{\mathrm{a}}$ & $114.79^{\mathrm{a}}$ & $185.97^{\mathrm{a}}$ & $3.96^{\mathrm{a}}$ & $8.37^{\mathrm{a}}$ & $66.67^{\mathrm{a}}$ & $18.97^{\mathrm{a}}$ & $8.23^{\mathrm{a}}$ & $17.95^{\mathrm{a}}$ & $66.85^{\mathrm{a}}$ \\
\hline OB & $7.07^{\mathrm{b}}$ & $61.65^{\mathrm{b}}$ & $174.28^{\mathrm{a}}$ & $2.46^{\mathrm{b}}$ & $6.62^{\mathrm{b}}$ & $\begin{array}{l}48.20 \\
\mathrm{~b}\end{array}$ & $18.51^{\mathrm{ab}}$ & $5.23^{\mathrm{ab}}$ & $14.25^{\mathrm{a}}$ & $56.93^{\mathrm{a}}$ \\
\hline OBR & $6.88^{\mathrm{b}}$ & $72.43^{\mathrm{b}}$ & $143.24^{\mathrm{b}}$ & $1.83^{\mathrm{b}}$ & $4.90^{\mathrm{c}}$ & $13.07^{\mathrm{c}}$ & $16.98^{\mathrm{b}}$ & $4.94^{\mathrm{ab}}$ & $2.57^{\mathrm{b}}$ & $10.26^{\mathrm{b}}$ \\
\hline $\begin{array}{l}\text { Overa } \\
11 \\
\text { mean }\end{array}$ & 6.51 & 66.70 & 134.46 & 2.15 & 5.20 & 32.07 & 14.65 & 4.95 & 8.70 & 33.65 \\
\hline
\end{tabular}

Means with the same superscript letter(s) in the same column are not significantly different $(P \leq 0.05)$ following Separation by Duncan Multiple Range Test.

Genotypes:

$\mathrm{ASL}=$ Ashley, $\mathrm{MK}=$ Marketer, $\mathrm{MM}=$ Market more, $\mathrm{P} . \mathrm{ST}=$ Poinsett, $\mathrm{SM}=$ Supper marketer

Parameters: VL21DAS = Vine length at 21 days after sowing, VL5WAS $=$ Vine length at 5 weeks after sowing

VL8WAS $=$ Vine length at 8 weeks after sowing, LV5WAS $=$ Lateral vines at 5 weeks after sowing

LV8WAS= Lateral vines at 8 weeks after sowing, FL $=$ Fruit length, FD $=$ Fruit diameter,FW $=$ Fruit weight

Table 3: Combined analysis yield and growth parameters in cucumber at four environments

Means with the same superscript letter(s) in the same column are not significantly different $(P \leq 0.05)$

Environments: $\mathrm{IK}=\mathrm{Ikom}, \mathrm{OB}=$ Obudu, $\mathrm{OBR}=$ Obubra, $\mathrm{CAL}=$ Calabar

VL21DAS = Vine length at 21 days after sowing VL5WAS = Vine length at 5 weeks after sowing, VL8WAS= Vine length at 8 weeks after sowing, LV5WAS= Lateral vines at 5 weeks after sowing, LV8WAS= Lateral vines at 8 weeks after sowing, $\mathrm{FL} \quad=$ Length of fruit, $\mathrm{FD}=$ Diameter of fruit, $\mathrm{FW}=$ Weight of fruitNFP = Fruits number per plot.

The production potential of an environment is the ability of the environment to support superior performance from a series of genotypes. This was evident at IK location where all the attributes evaluated performed consistently better than other locations.

\section{AMMI Stability Value.}

The AMMI analysis of variation for yield $\left(\mathrm{t} \mathrm{ha} \mathrm{h}^{-1}\right)$ of five genotypes of cucumber tested at four locations and its stability value is presented in (Tables 5 and 6). Based on this model, fruit yield showed significant variation for both main and interaction effect at $(p<0.001)$ indicating a wide range of variation between the genotype, environments and their interaction. The significance showed by $G \times E$ implied that each of the genotype reacted differently in various environment evaluated. The additive component of the analysis, results revealed that the mean squares of the IPCA1(the first interaction principal component axis) was highly significant $(P<0.01)$ for genotype, environment and the interaction. The treatment sum of squares due to GEI of the multiplicative variance of was divided into IPCA1 and IPCA2 (interaction principal component analysis) and residual variation. IPCA 1 of the interaction sum of squares explained $96.7 \%$, IPCA2 explained $3.1 \%$ and residual explained $0.21 \%$.

IPCA1 was greater than IPCA2 sum of squares showing the presence of differences in fruit yield performance of the cucumber genotypes as a result of the interactive effect. This indicated that, one basic factor influenced the GEI which could be genotypic or environmental in nature. This result is in conformity with the findings of Vasanthumaret al.(2015) on water melon and Felix et al. (1997) on cucumber. Both results of the combined analysis of variation (ANOVA) and AMMI analysis of variation showed that environment $(E)$ constituted the highest variation source accounted for $59.60 \%$ of the total sum of squares (TSS), while genotype (G) $15.83 \%$ (GE) Interaction source of variation accounted for $11.89 \%$ error $6.64 \%$ and replication $6.02 \%$ of the total variation, respectively.

The genotype stability and adaptability over range of environments is indicated by the IPCA scores in AMMI analysis. The greater the IPCA score not minding the positive or the negative sign the more specific adapted genotypes to certain environments. The closer the IPCA with small scores close to zero have low interaction and stable, genotype ASL had the most stable yield across environment compared to P.ST, MK, MM and SM. By considering the IPCA1 alone genotype ASL scored the lowest and it is considered the most stable both in 
favorable and unfavorable environments. Genotypes P.ST, MK and ASL, maintained high yields in all the environments implying that they are adaptive to the locations, so they could be deployed in the locations or used for subsequent improvement of stable genotypes. $\mathrm{SM}$ and $\mathrm{MM}$ were determined to be poorly adapted to all the environments with their resultant low yields in the entire environments.

The AMMI Stability Value (ASV) for the five genotypes was computed. Lower ASV genotypes are considered more stable than the higher ASV genotypes. According to the ranking, based on this model, irrespective of their signs, ASL had the lowest ASV, so it was considered the more stable followed by MK, whereas genotypes P.ST, MM, SM were unstable (Table 6). Quantitative stability measure is very important for quantifying genotypes based on their yield stability rank yet AMMI model does not provide such measurements.

In AMMI 1 model bi-plot, the plot visualized the productivity average of the varieties, locations and their interactions, (Yan and Hunt, 1998).

There was overlapping of genotypes across the environments indicating that crossover interactions among the genotypes occurred (Fig. 1). There was an interaction at $\mathrm{IK}$, among the high yielding genotypes in this order (P.ST > MK > ASL). Crossover interaction occurred at OB with ASL crossing over P.ST and MK in the following order (ASL>P.ST>MK). There was also a crossover between P.ST and MK, at OBR, (ASL >MK $>$ P.ST). Crossover interaction between the low yielding genotypes, only took place at OBR with MM crossing over SM.

Table 5: ANOVA table for AMMI model

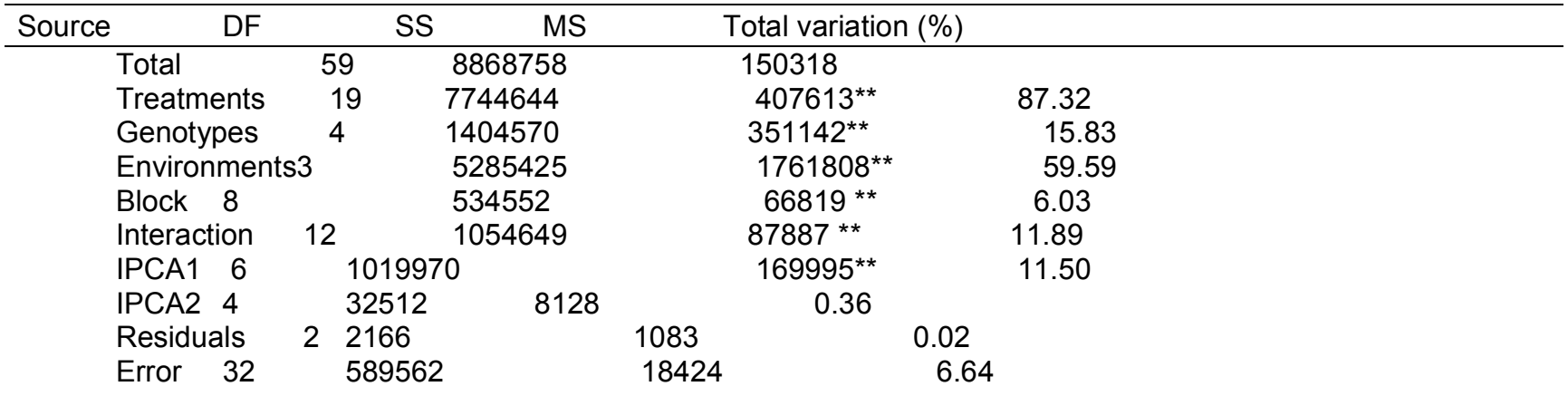

** And ${ }^{*}=$ significant level at $P<0.01$ and $P<0.05$ respectively; ns=not significant; and $\mathrm{df}=\mathrm{degree}$ of freedom, $\mathrm{E}=$ environment; $\mathrm{G}=$ genotype; I = genotype environment interaction

$\mathrm{AMMI}=$ Additive main effect and multiplicative interaction

TABLE 6: AMMI Stability Values of Genotype Yield Performance

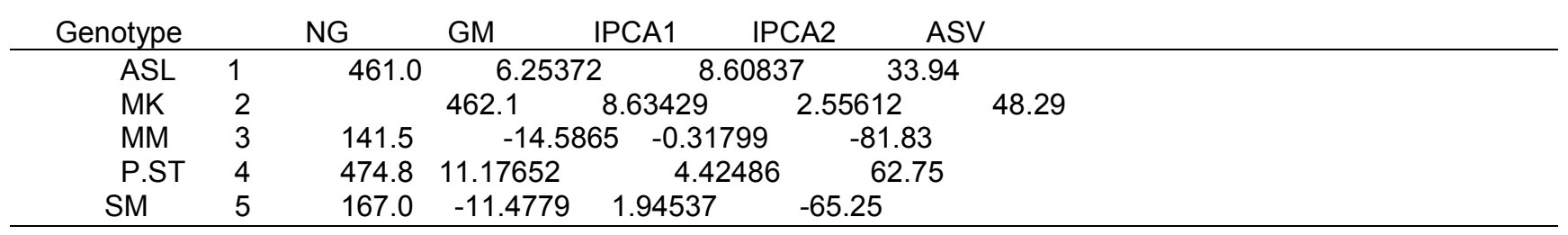

key

$\overline{\mathrm{NG}}=$ Number of genotype, $\mathrm{GM}=$ Genotype mean, IPCA1=Interactive principal component analysis 1 IPCA2=Interactive principal component analysis 2, $\mathrm{ASV}=\mathrm{AMMI}$ Stability Value, $\mathrm{ASL}=$ Ashley, $\mathrm{MK}=$ Marketer

$\mathrm{MM}=$ Market more, P.ST $=$ Poinsett, $\mathrm{SM}=$ Supper marketer

The above result agrees with the report of Vijendra Das (2005) that when cultivars are compared in different environments, their performance relative to each other may not be the same. One genotype could perform in one environment and the second may supersede in others. It was very evident from (Fig.1) that Ashley had the highest at Obudu and Obubra. But Poinsett excels at Ikom. Between the poor yielders, Market more was highest at Obubra, but Supper Marketer excels at Obudu and Ikom.

The genotypes $\mathrm{x}$ environment interactions are of immerse importance to breeders in many ways; the necessity for breeding ideotypes is actuated by the knowledge of the interaction of genotypes with predictable environmental factors. Special genotypes may be needed for different environment. The response of genotypes to unstable productivity levels among environments provides an understanding of the stability of performance. This further provides the understanding of the environmental stability of genotypes and the determination of their suitability for the irregularity in growing conditions that could be encountered.

The four environments were grouped based on their productivity potential as indicated by their scores on the 
AMMI 1 Bi-plot presented in Fig 2. The bi-plot has four quadrants with environments and genotypes grouped in only two quadrants out of the four. The grouping of the environments in to two quadrants indicated the importance of AMMI model in establishing the distinction among environments in terms of conditions necessary for potential growth.

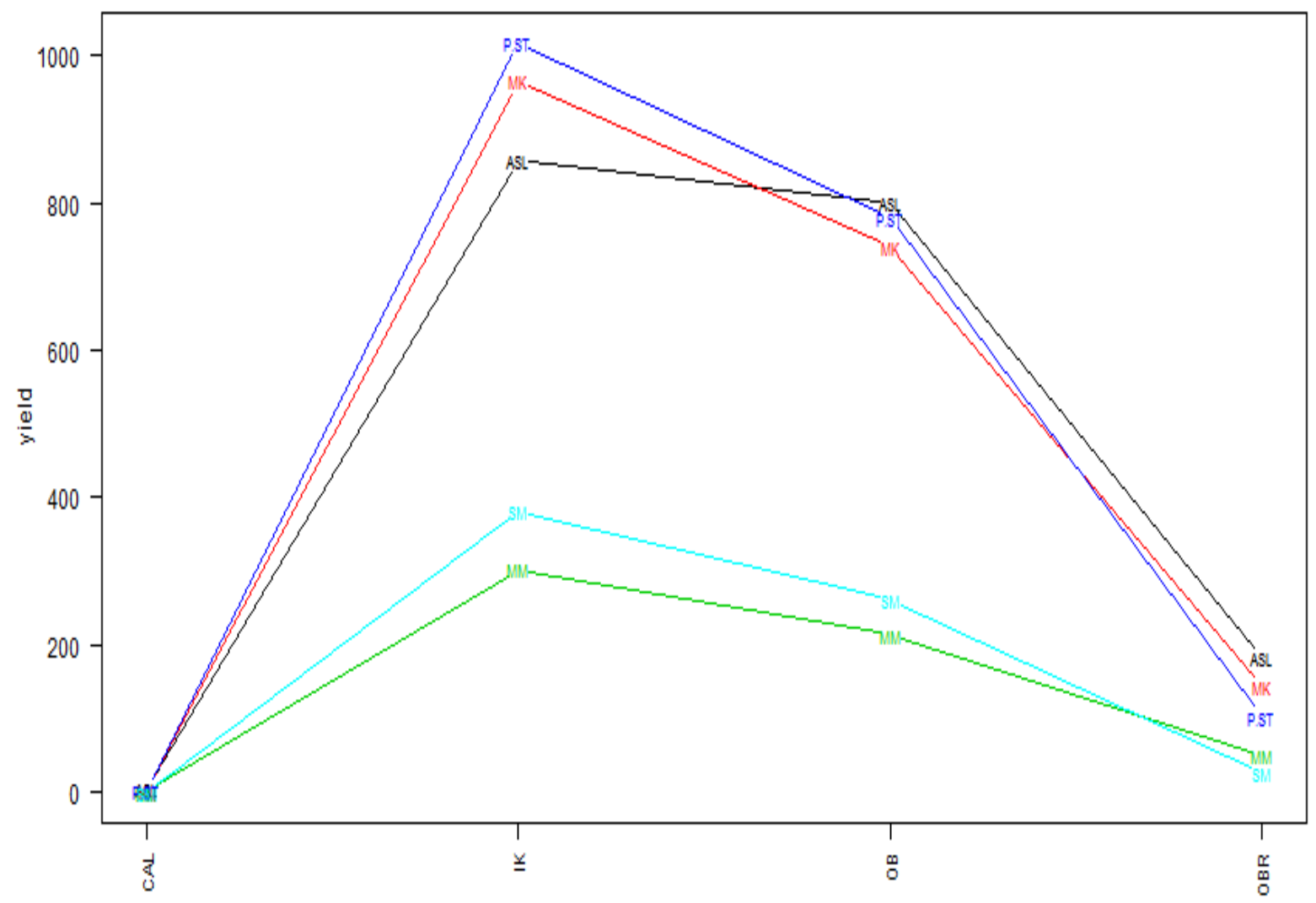

Environment

Figure 1: GGE bi-plot of yield response and cross over interaction of genotypes across environment.

Key: Env.=Environment; $\mathrm{ASL}=$ Ashley; $\mathrm{MK}=$ Marketer; $\mathrm{MM}=$ Market more; $\mathrm{P} . \mathrm{ST}=$ Poinsett; $\mathrm{SM}=$ Supper marketer; IK = Ikom; OB = Obudu; OBR = Obubra; $\mathrm{CAL}=$ Calabar

This aspect is very crucial because environments are selected based on the similarity of response and suitability. This is very essential in decision making for selection of best environments and genotypes, thereby reducing the cost for commercial farmers. Based on the AMMI 1 bi-plot, environments IK and OB had the highest environmental mean yields; they were grouped together indicating their similarities in terms of yield performance. Genotypes ASL, MK and P.ST had the highest genotypic mean yields and were grouped together in the same quadrant with the highest environments. This showed that these genotypes (ASL, MK and P.ST) were very responsive to favourable environments. Environments CAL and OBR, according to the AMMI1 bi-plot were grouped together in the same quadrant with genotypes MM and SM having both low environmental and genotypic mean yields indicating that they were unfavourable environments for the production of cucumber. 


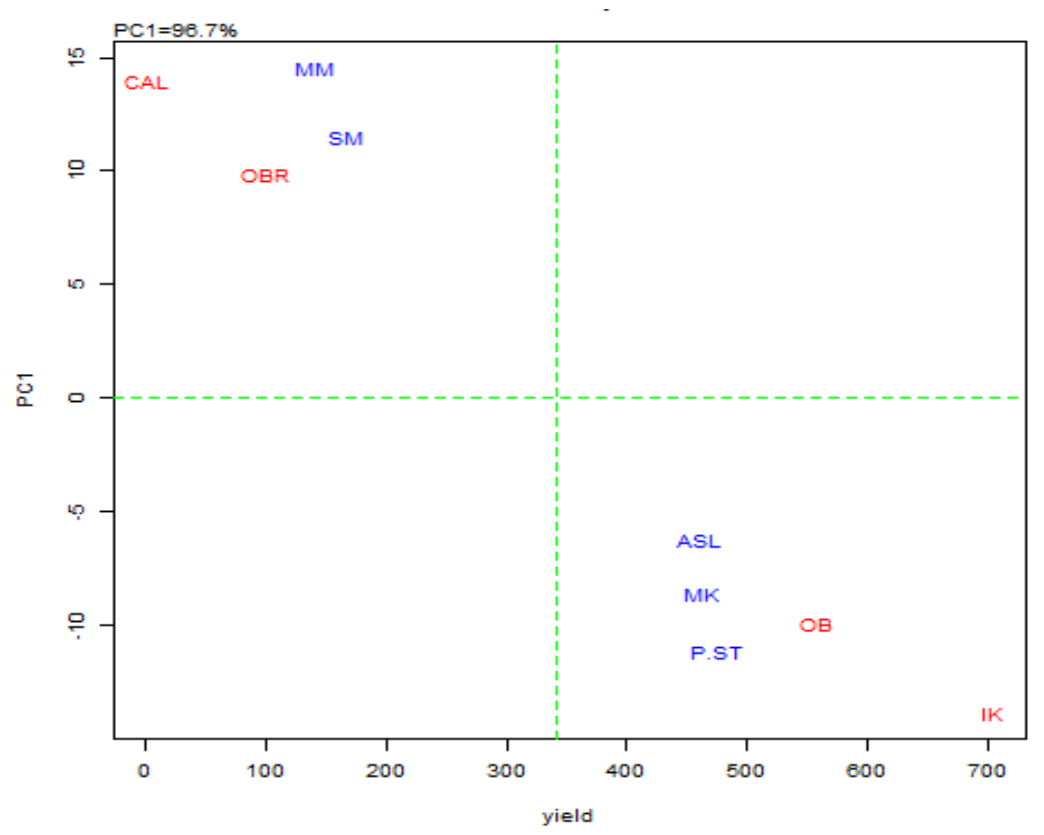

Figure 2: AMMI bi-plot: fruit yield $\left(\mathrm{t} \mathrm{ha}{ }^{-1}\right) \times$ IPCA1.

Key $: \mathrm{PC} 1(\%)=$ Principal component $; \mathrm{ASL}=$ Ashley; MK= Marketer; $\mathrm{MM}=$ Market more; $\mathrm{P} . \mathrm{ST}=$ Poinsett; $\mathrm{SM}=$ Supper marketer; $\mathrm{IK}=\mathrm{Ikom} ; \mathrm{OB}=$ Obudu; $\mathrm{OBR}=$ Obubra; $\mathrm{CAL}=$ Calabar

\section{GGE Bi-plot Analyses}

Fig.3. presents the polygon view of GEI for five the genotypes over four test environments tested. The polygon view of the bi-plot is the easiest means of visualizing the interactions effect of genotypes and environments (Yan and Kang, 2003), to show the cross over GE interaction is present or not, which helps to estimate of mega-environments possibly if they exist (Guach and Zobel, 1997, Yan and Rajcan, 2002). The pictorial viewof the "Which-won-where" pathway of locational trial data information is essential to explore mega environment in the production areas, (Guach and Zobel 1997).A polygon was formed to show "which-won where" by linking the genotypes at the vertexwith straight lines and one of the genotypes placed within the polygon. The vertex genotype in each sector is the best genotype at environments whose markers fall into the respective sector.Environments within the same sector share the same winning genotype, and environments in different sectors have different winning genotype. The partitioning of the GEI through the GGE bi-plot analyses revealed that Principal component 1 and Principal component 2 accounted for $98.2 \%$ and $1.7 \%$ of the genotype + genotype environment sum of squares respectively in (Fig 3 ). This explains the variation of $99.9 \%$. These vertex genotypes in this study were (P.ST), (ASL), (MM) and (SM). They were either the highest yielders or the lowest yielders in some of the environments; therefore they were farthest from the origin of the bi-plot. On the account of the polygon view, the genotypes fell into three sections and the test environments fell into two sections. The first section hadlkom (IK) Environments within the same sector share the same winning genotype, and environments in different sectors have different winning genotype. 


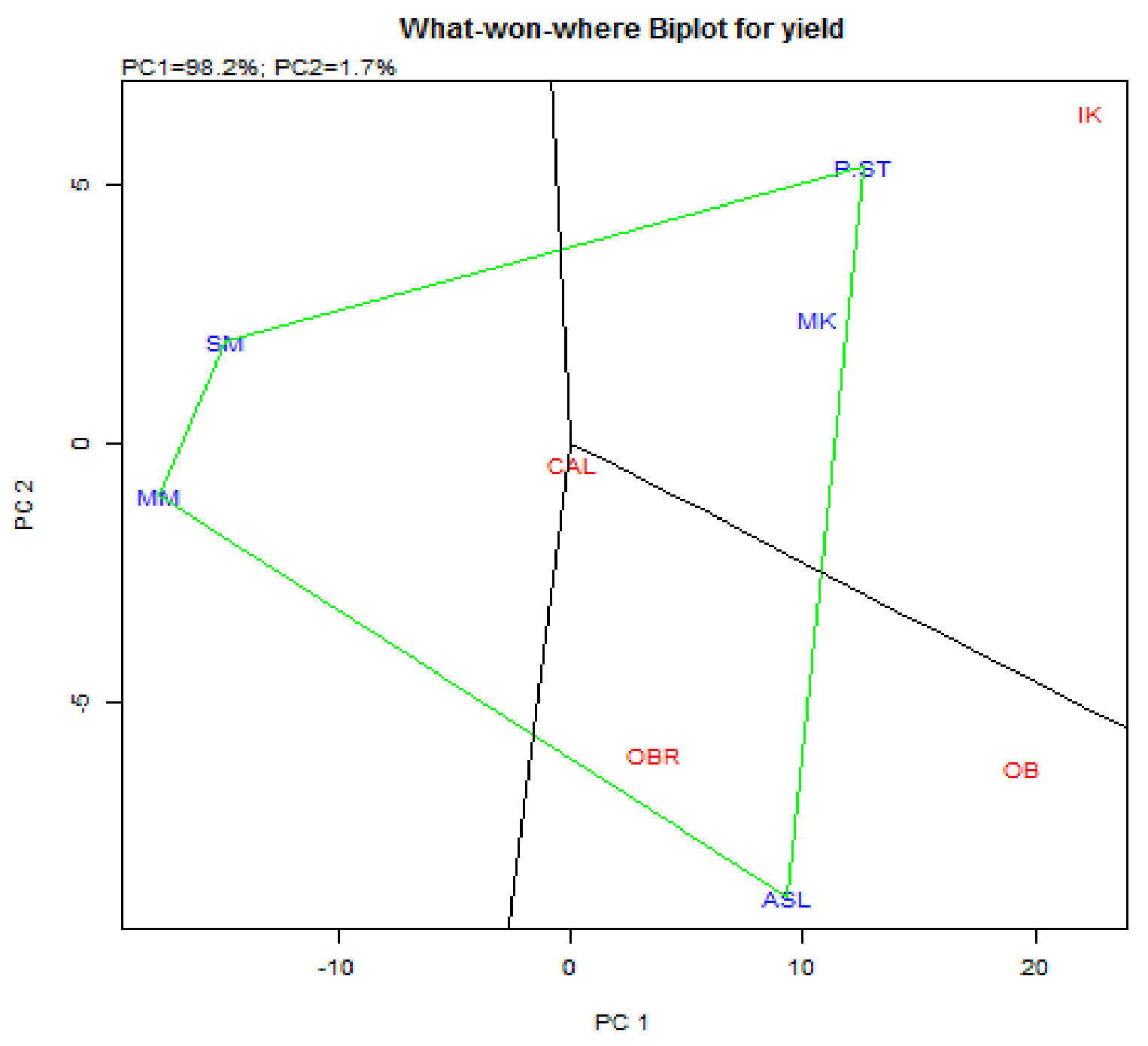

Fig.3. polygon view of genotype $x$ environment interaction for five cucumber genotypesover four test environments; PC1=First Principal component; $P C 2=$ Second Principal component $; A S L=$ Ashley

$\mathrm{MK}=$ Marketer; $\mathrm{MM}=$ Market more; $\mathrm{P} . \mathrm{ST}=\mathrm{Poinsett} ; \mathrm{SM}=$ Super Marketer; $\mathrm{IK}=\mathrm{Ikom} ; \mathrm{OB}=$ Obudu $\quad ; \quad \mathrm{OBR}=$ Obubra; $\mathrm{CAL}=$ Calabar

This had the genotype Poinsett (P.ST) as the best yielder.Obudu (OB), Obubra (OBR) and Calabar (CAL) where Ashley (ASL) was the best variety. From the GGE bi-plot graphical representation, the vertex genotypes (MM) and (SM) were not top yielding in graphical representation, the vertex genotypes (MM) and (SM) were not top yielding in any of the environments. This study is in conformity with the reports of Ezatollahet al., (2014) in wheat-barley disomic addition lines.

\section{An ideal genotype evaluation}

Genotypes relative to an ideal genotype are shown (Fig.4). The ideal genotype according to Yan and Kang (2003) is a genotype with high mean performance and absolute stability. The length of the vector determines the ideal genotype. An ideal genotype must have high yield across the locations with zero GEI. (Ezatollah et is used as a yardstick for genotype evaluation. On this basis a concentric circles were drawn with the ideal genotype as the core. This enables the view of the genotypes distances from the ideal genotype. The genotypes were represented according to their code as shown in Fig 4. The genotype ASL (Ashley) was more ideal, hence, it was the closest to the ideal genotype, the order ofranking relative to the ideal genotype was as follows; ASL>MK>P.ST. The lower yielding genotypes $\mathrm{SM}>\mathrm{MM}$, were not favoured therefore, they are located far away from the position of the ideal genotype. In line with the graphical representation, thegenotype, Poinsett (P.ST) had the longest vector which indicated that it had the highest mean fruit yield and Market More (MM) had the lowest mean fruit yield (Fig.4).The genotype found ideal can be used as an advertence for genotype assessment. 


\section{CONCLUSION:}

A genotype Ashley which has relative consistent yield performance in the three environments (Obudu, Obubra and Calabar) according to Baye and Wilke (2010) possesses a broad-based adaptation to environmental factors.(Soil type, temperatures, soil nutrient). Tesifayeet al. (2011) reported that the growth and the totality of plant are often impacted by its environments. They maintained that the presence of a particular variety in a given environment is mediated by the genetic component which enables the genotype to adapt to a particular environment.

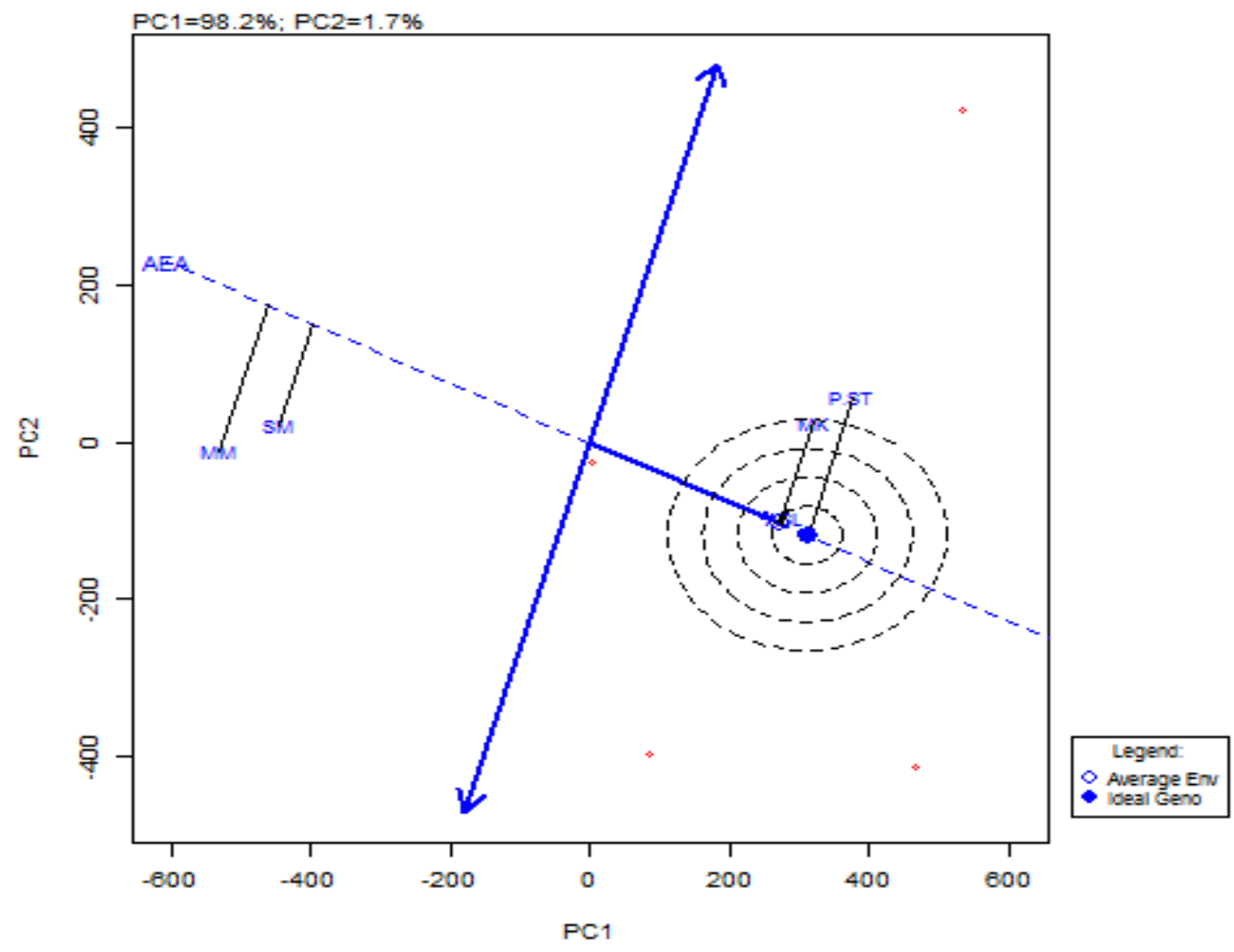

Fig. 4. GGE Bi-plot - Genotype View for yield based on ideal genotype.

\section{REFERENCES}

Allard R.W. \& Bradshaw, A.D., 1964. Implication of genotype $\mathrm{x}$ environment interaction in applied plant breeding. Crop Science, 5:503-506.

Best, K., 2000.Adaptation of cabbage varieties. ARP. Training Reports.

Ceccarelli, S. \&Grando, S., 1993. From conventional breeding to molecular biology.Pp. 533-557 in D.R. Buxton et al., (Ed.).International Crop Science, 1 CSSA, Madison, WI USA.

Comstock, R.E. and Moll, R.H., 1963. Genotype x Environment interactions. In: Hanson, W.D; Robison, H.F (eds), statistical genetics and plant breeding. National Academy of ScienceNational Research Council Publication, 982, Washington D.C ., PP 164-196.

Delacy, I.H., Copper, M., and Basford, K.E., 1996. Relationships among analytical methods used to study Genotype by Environment Interactions and the numluntion of thair imnont an mannonon to selection. In: Kang M.S., and Guach H.G.(eds), Genotype by Environment Interactions. CRC Press New York; pp.51-84.

Derera, J., Tongonna, P., Pixley, K. V., Vivek, B., Laing, M. D., \& Rij, N. C., 2009.Gene action controlling grey leaf spot resistance in South African maize germplasm.Crop Science, 48: 93-98.

Ezatollah, F. \& Mahsa, S., 2014. GGE Bi-plot Analysis of genottype $x$ environment interaction in wheat Agropyron Disomic Addition lines.Agricultural communications, 2(3):1-7

Felix, C. Serquen, J. B. \& Jack E. S.,1997.Genetic analysis of yield component in cucumber at low plant density.Journal of American society of Horticultural science, 122(4): 522-528.

Food and Agricultural Oganisation Statistics (FAOSTAT) 2015. Top ten Cucumber producing Countries in the World 2015. Retrived July 29, 2015, from www.fao.org/3/a-1454e.pdf 
Guach, G. H. \& Zobel, R.W.,1997.Identifying megaenvironments and targeting genotypes.Crop Science, 37: 311-326.

Hector, V., Randall, T. Y. \& Steve F., 1989.Field Cucumber production Guidelines for Hawaii.

Jack E. S., Mathew, D. R., Todd C. W., 2008. Handbook of Plant Breeding, 1: 241-282

Kang, M.S. 1998. A new SAS programme for calculating stability-varience parameters. Journal of Heredity 80:415.

Lee D. H., Iwanski, G. B. \&thoenniseen N.H 2010.Cucurbitasins: ancient compound shedding new light on cancer treatment. Scientific world Journal, 5(10): 413-8.

Makumbi D., 2005.Phenotypic and genotypic characterization of white maizeinbreds, hybrids and synthetics under stress environments.Ph.D. dissertation submitted to the office of graduate studies of the Texas A and M University.

Nzuve, F., Githiri S, Mukunya D. M. \& Gethi, J., 2013 Analysis of genotype $x$ environment interaction for grain yield in maize hybrids. Journal of Agricultural Science,5, NO.11

Purchase, J. L., 1997.Parametric analysis to describe genotype $\mathrm{x}$ environment interaction and yield stability in winter wheat. Ph.D. Thesis, Department of Agronomy, Faculty of Agriculture of the University of Free State Bloemfontein, South Africa

Tesfaye, M. Baye, K. M., Biagini M. J M., Martin L. J., Lindsey, $M$. and Patterson T .L 2011.Differences in candidate gene association between European Ancestry and
African American Asthmatic Children.Journal of pone 6(2):

Thanki, H. P. Sawargaonka S. L \&Hudge B. V, 2010. Genotype $x$ environment interaction for biometrical trait in pigeon pea (cajanusccajan Lmillsp) undev. Varying spacings, Electronic Journal of Plant Breeding 1(4)925-938.

Thoa, D. K. 1998.Cucumber seed multiplication and characterization. AVRDC- ARC training, Thialand.pp 23-26

United States Department of Agriculture (USDA), 2014. Natural Nutrients, Database for Standard reference, Released 27: 128.

Vasanthkumar, A. M., Shirol, RavindraMulge, Thammaih N. and Prasakumar 2012. Genotype X environment interaction in water melon (Citriluslanatus Thumb.) 25(2):248-252

Vijendra, L. D. Das, 2005. Genetic \& Plant Breeding.Pp 76-79. New Age International Limited, Publisher: New Delhi.

Yan, W. \& Kang M.S. 2003. GGE Bi-plot Analysis and graphical tool for Breeders, Geneticists and Agronomists.CRC Press LLC Boca Raton, Florida, Pp. 267.

Yan, W. \&Rajcan, I. 2002. Bi-plot analysis of test sites and traits relation in Ontario. Journal of Crop Science, 44, 11-20.

Yan, W., Hunt, L.A Sheng, Q. \&Szlannics. 1998. Cultivar evaluation and mega-environment investigation bed on the GGE bi-plot. Crop Science. 40:597605

Zobel, R.W.,Wright M.J \&Guach G.H., 1988. Statistical analysis of yield trial. Agronomy Journal, 80:388-393. 